\title{
HISTORICAL AND CULTURAL HERITAGE OF THE REGION AND ITS OPPORTUNITIES IN TOURISM AND EXCURSION ACTIVITIES (CASE OF CHERNIVTSI REGION, UKRAINE)
}

\author{
Volodymyr KROOL \\ Yuriy Fedkovych Chernivtsi National University, Department of Physical Geography, Geomorphology \\ and Paleogeography, 2 Kotsyubynsky Str. Chernivtsi 58012, Ukraine, e-mail: kroolv@ukr.net
}

\begin{abstract}
Anatolii VDOVICHEN
Chernivtsi Institute of Trade and Economics of KNUTE, Department of Management and Tourism, 7 Tsentralna Square, Chernivtsi 58002, Ukraine, e-mail: danjapolina@ukr.net

Roman HYSHCHUK*

Chernivtsi Institute of Trade and Economics of KNUTE, Department of Management and Tourism, 7 Tsentralna Square, Chernivtsi 58002, Ukraine, e-mail: groma2006@gmail.com
\end{abstract}

\begin{abstract}
Citation: Krool, V., Vdovichen, A., \& Hyshchuk, R. (2018). HISTORICAL AND CULTURAL HERITAGE OF THE REGION AND ITS OPPORTUNITIES IN TOURISM AND EXCURSION ACTIVITIES (CASE OF CHERNIVTSI REGION, UKRAINE). GeoJournal of Tourism and Geosites, 23(3), 808-823. https://doi.org/10.30892/gtg.23316-330
\end{abstract}

\begin{abstract}
Chernivtsi region in Ukraine is a unique territory where the historical and cultural heritage of different time periods is represented: from Old Russian, Ottoman, Austro-Hungarian to Romanian and Ukrainian. The purpose of the article is a comprehensive assessment of the historical and cultural heritage of the Chernivtsi region for a more intensive further involvement in the tourism industry in the Carpathian region, together with neighboring EU countries: Romania, Slovakia, Poland. For this purpose, different status, state of preservation and spatial differences were taken into account together with the resources support throughout the territory under study. The article considers the theoretical and methodological foundations for studying the historical and cultural significant sites of the region, carries out a comprehensive assessment of the historical and cultural potential of the Chernivtsi region, analyzes its legacy through three factor components of ratings: the number, concentration and location of tourist destinations (archaeological sites, monuments of architecture, history and monumental art). The result is an integral grade rating of the Chernivtsi region and its regional taxonomic units of the lowest hierarchy, which have the greatest concentration of historical and cultural tourist destinations. According to the studies of the territory the most suitable for effective and perspective use in domestic and international tourist and excursion activities, but the North Bukovyna recreational supra-region occurred to be weak promotional and organizational component of the integral touristic product.
\end{abstract}

Key words: cultural and historical resources, heritage, tourist and excursion activities, tourist destination, quest-excursion, Bukovyna, Northern Bessarabia

\footnotetext{
* Corresponding author
} 
Historical and Cultural Heritage of the Region and its Opportunities

in Tourism and Excursion Activities (Case of Chernivtsi Region, Ukraine)

\section{INTRODUCTION}

Now there is active unification of Ukraine with the world cultural environment, a comprehensive and adequate clarification and analysis of its historical and cultural heritage $(\mathrm{HCH})$ for rational use and special protection is the most important state, international, humanitarian and practical task of science. The need for expert assessment of the capabilities of the historical and cultural heritage of the region is traced in the actualization of its effective application for the future. This is reflected in the system and structural justification of the location of a certain resource in the study area, the identification of forms and methods for its development that are fair in this resource, especially in tourist and excursion activities, and ensuring coordinated rules for all interested in the opening up, development and use of the historical and cultural heritage.

However, despite the substantial methodological and practical component that has been implemented in the field of historical and cultural heritage by foreign and domestic researchers, there is no innovative generalizing research in this field, especially if it concerns the post-Soviet space within its countries and regions. Until recently, the issue of historical and cultural heritage assessment was not a part of scientific research and practical application to identify the region's total potential, its development guidelines and its use in tourism and excursion activities. However, with Ukraine's signing of an agreement on associate membership with the EU in 2014 and the implementation of related reforms on the decentralization of the economy, the vectors of Ukraine's development have changed, including in the field of tourism business, so the urgency of research of this kind has increased dramatically.

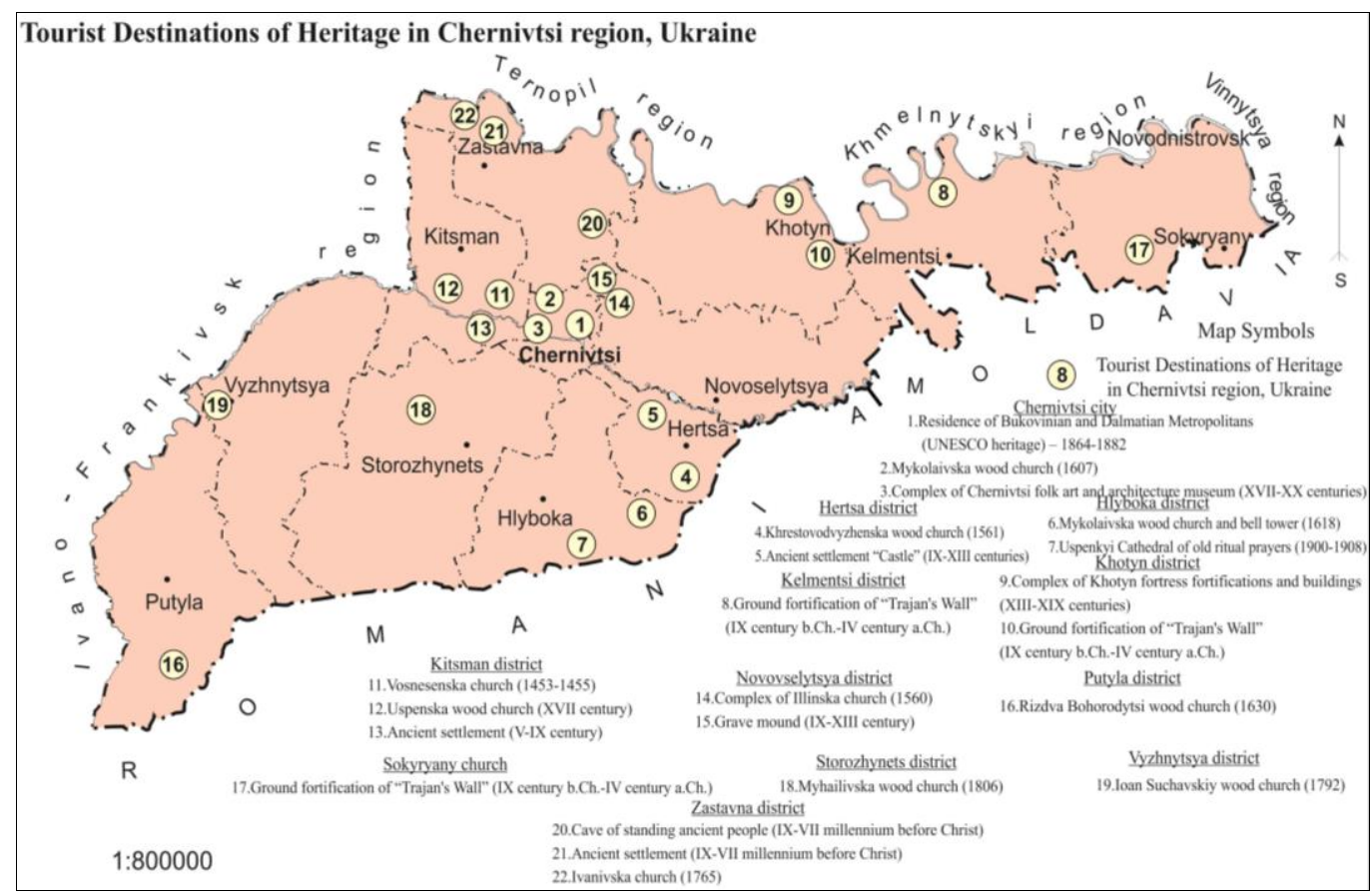

Figure 1. The map of geographical location

of the study area and the main its tourist destinations of heritage 
These events have caused an acute need for in-depth geographical study of the local territories with a significant resource potential, but in need of grant or investment funds for the development and restoration of their infrastructure, the organization of preservation of tourist and excursion destinations or the promotion of their activities at the local level or for cross-border cooperation with the EU countries. The urgent need to answer these questions determined the choice of the research topic, tasks, assessments and perspective directions of the operation of the historical and cultural heritage of the Chernivtsi region as a border region with the EU (Figure 1) and the territory of the Carpathian recreational zone within Ukraine, Romania, Slovakia and Poland.

Today, scientists whose research studies are focused on history, archeology, ethnography, philology, art criticism, culturology, etc. are engaged in the assessment of the cultural heritage. However, despite so much interest from scientists, the use of historical and cultural heritage in tourist and excursion activities is not given enough attention, even though there is now a separate discipline "Tourist Local Studies" in the curriculum of Ukrainian universities. It should be noted that the assessment of the regional historical and cultural heritage is concentrated by Ukrainian and foreign scientists mainly on the descriptive part of its placement or studying only the material component and the list of recreational or tourist resources. In addition, the content of scientific research for determining the object of research is reduced to a management system of historical and cultural significant sites (hereinafter HCSm), however, territories that have the greatest or best prerequisites and potential are not specified.

Thus, the issue of the unconditional connection between tourism and the historical and cultural heritage is considered in the research "Tourism and development of Malta". In it, the author emphasizes the exceptional role of the island's cultural heritage (historical monuments, crafts, art, music and even parish feasts) for the promotion of domestic and international tourism (Boissevain, 1977). The process of forming a tourist product and its composition, which must necessarily cover cultural attractions, was in the field of vision of the Nigerian scientist Dr. Franklin J. (Adejuvvon, 1985). The lack of attraction of cultural monuments to the tourism sector was noted in the work "Selling art and history: cultural heritage and tourism". In it, the authors draw attention to the advisability of including in the tourist product of the cultural heritage not only the HCS, but also museums, art galleries, historical theme parks and arts festivals. In the Soviet scientific space, questions of the methodology for assessing the HCS and objects, palace and park and estate complexes, and significant nature sites by their importance were investigated. The quantitative characteristics of the historical and cultural potential (hereinafter HCP) were presented through the number of objects of tourist attraction of different significance levels, according to the classification of objects of international, federal, regional and local level (Pirozhnik, 1985, Litovka, 1990).

The theme of the research on the historical and cultural heritage in the former Soviet Union was revived, while simultaneously developing beyond its borders. In particular, M. Kuznetsov made complex zoning of historical places, monuments of culture and architecture, nature, and museums for the development of tourist and excursion activities in the Crimea. He used indicators of the number and density of the location of cultural and historical objects for $1000 \mathrm{~km}^{2}$ for the parametrization of scientific conclusions (Kuznetsov, 1995). Separately, the density of monuments of the highest class of national and international significance per $100 \mathrm{~km}^{2}$ was suggested for use in tourism science by V. Matsola. To do this, the scientist used the national density rating scale of the historical and cultural heritage of national status, which he compared with the indicators of Ukraine and the Lviv region: less than the average Ukrainian score is estimated 1 point, 
Historical and Cultural Heritage of the Region and its Opportunities

in Tourism and Excursion Activities (Case of Chernivtsi Region, Ukraine)

the average regional is 2 points, and more than the average is 3 points (Matsola, 1997). According to the same principle of density of HCS, the Carpathian recreational region was assessed by V. Evdokymenko (Evdokymenko, 1996). Pavlov and Cherchyk have divided historical and cultural heritage into three categories of importance for tourist-excursion activity at the level of the region. In their opinion, especially valuable objects for the organization of the specified activity in tourism are attributed to the first category, the objects having significant interest for tourists to the second, and other objects to the third (Pavlov \& Cherchyk, 1998). The importance of the influence of Baroque historical and cultural heritage on tourism development in Sicily was studied by Tiziana Cuccia and Cellini Roberto. The results of the ranking sample of the tourist visit to Shikli city were based on factor analysis of the seasonal impact, socio-demographic indicators and the diversity of the city's historical and cultural heritage (Cuccia \& Cellini, 2007). The work of Aline Chiabai, Stephen Platt and Wadim Strielkowski was dedicated to the evaluation of e-services in tourism and promotion of their cultural heritage in Amsterdam, Genoa and Leipzig (Chiabai et al., 2014). The association between the sustainable development of tourism and its impact on the cultural heritage and the environment of countries at different levels of economic development in this context is revealed in the writings of Harry Coccossis (Coccossis, 2009).

Thus, this article is almost the first attempt to give a detailed final assessment of the historical and cultural heritage within the Chernivtsi region as a border area with the $\mathrm{EU}$, to enhance the development of tourist and excursion activities. In all of the studies analyzed above, the Chernivtsi region was not in the focus as an independent geographic object, and the comprehensive assessment of the historical and cultural heritage made in the regions of Ukraine (Beydyk, 2001; Polyvach, 2012) did not reflect the internal territorial differences of the regions themselves according to administrative units of lower rank, and did not take into account the "weight" of historical and cultural heritage objects by their status and integrity. Under the current reform of decentralization of the economy (after 2014), this situation deprives local governments of an understanding of the rational allocation of funds in the regions to those areas where they correspond to the greatest potential for developing their attractiveness, hence the relevance of such research is growing. An additional argument for the importance of the chosen topic is that, according to Polyvach and the Institute of Geography of the Academy of Sciences of Ukraine, Chernivtsi region has a high heritage potential but a low level of use (Polyvach, 2012, p. 133). Based on the above, the first task of the work is to take into account not only the quantitative territorial values, but also the "status weight" (points) when assessing four types of historical and cultural objects (archaeological, architectural, historical and monumental art) that was suggested for the first time. At the next stage, it will be important to calculate the total scores for each of the four types of historical and cultural heritage objects, in particular for the three components: scoring their number, taking into account the "status weight", the modified indicators of the concentration of objects and the coefficients of their localization. The cartographic model of the total rating positions of each administrative unit of the region, covering the total number of points from the three components evaluated by the authors with four types of historical and cultural heritage, will be one of the results of the study. In the end, this will make it possible to identify the main territorial units of large, medium and small potential of the historical and cultural heritage integral value. It should be noted that the results of the work and the methodology for calculating the rating positions of administrative-territorial units by the total value of the historical and cultural heritage can be used by other local self-government bodies and relevant institutions for effective management and development of their tourist and excursion activities. 


\section{METHODOLOGY}

The study of the region historical and cultural heritage (case of the Chernivtsi region, Ukraine) was carried out using the method of K. Polyvach, which was declared by her in her dissertation research and monographs in which she offers comprehensive geographic methods for an integral assessment of the cultural heritage of a region or regions (Polyvach, 2007, 2012). In contrast to the already existing dozens of methodological developments of scientists in assessing cultural heritage by several criteria (see Figure 2) and are focused on the study of only its material component, recreational and tourist resources (Piroshnik, 1985; Kuzyk \& Kasianchuk, 1993; Kartashevska, 1995; Kuznetsov, 1995; Bayteriakov, 1996; Matsola, 1997; Panchenko, 1998; Zavada, 1998; Beydyk, 2001; Pavlov \& Cherchyk, 1998, Pokolodna, 2003; Yakovenko, 2004; Filonenko, 2005; Cuccia, 2007), K. Polyvach's technique is stratified into two components, according to the level of its territorial coverage: the region and the district (city planning area). The difference of these approaches to the territories of different levels lies in the differences in the criteria that are the basis for the assessment, the relevant assessment indicators and areas of application. The proposed methodology makes it possible to identify the most effective and promising regions for the use of historical and cultural potential, to identify the region's prospective opportunities and to assess their attractiveness to a potential investor, to diagnose problem regions and to analyze possible causes of the emergence of problematic situations in them, to facilitate the development of recommendations for improving the efficiency of HCP use, create a basis for defining long-term goals and devise a strategy for the development of the region, and their main achievements through the implementation of grant, state and regional programs for the preservation of HCS and the development of tourism (Polyvach, 2007).

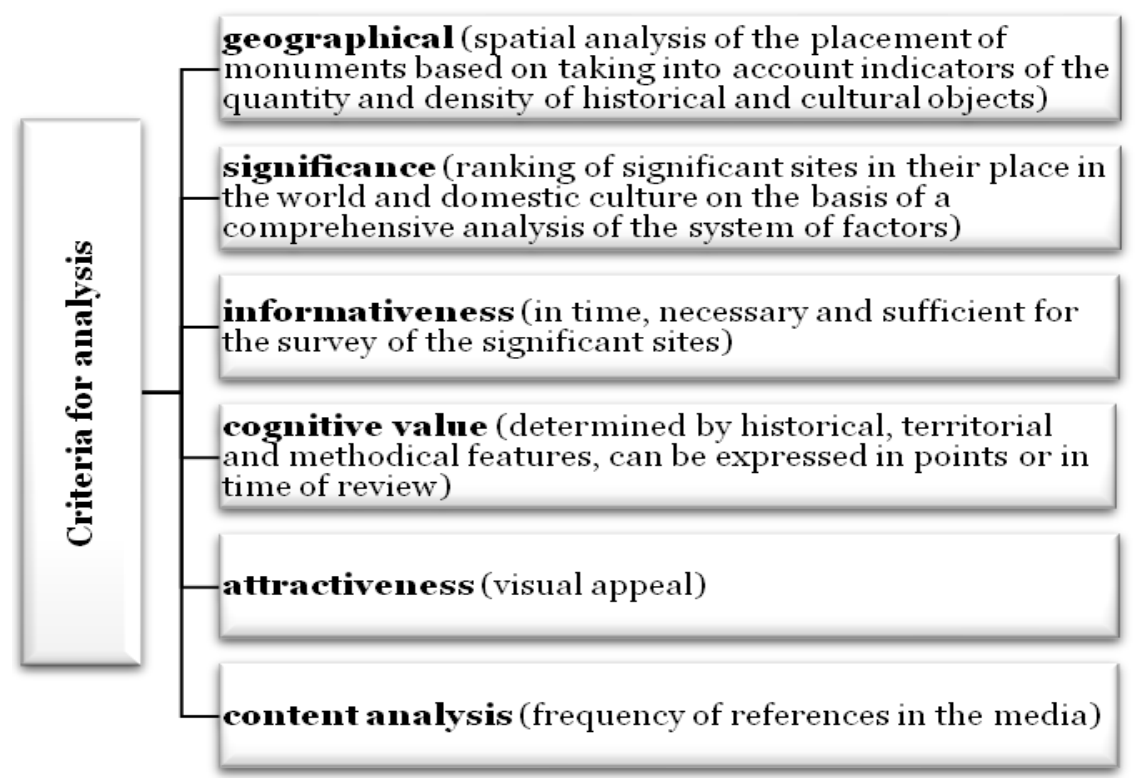

Figure 2. Criteria for analysis of historical and cultural heritage (Source: made by authors based on K. Polyvach, 2012, p. 49)

To ensure the correctness of the comparison of regions, in addition to general statistical indicators of the number of historical and cultural tourist destinations represented in the State 
Historical and Cultural Heritage of the Region and its Opportunities

in Tourism and Excursion Activities (Case of Chernivtsi Region, Ukraine)

Register of Monuments of Ukraine, the authors also used regional coefficients: the modified coefficient of concentration of tourist destinations and the localization coefficient of objects, calculated using geographical methods of research. The first factor in the partial rating of the regional historical and cultural heritage (namely, the Chernivtsi region) is their number. But for evaluation it is also necessary to take into account their conservation status or the degree of preservation. In other words, the total physical quantity of monuments of a certain region cannot act as a formative and prevailing potential, since not all monuments have the same value, given their status and suitability as a destination for use in tourism activities. That is why the authors suggest taking into account additional coefficients for a separate territorial unit in their common HCP. Therefore, in order to determine the status capacity of equally weighting sites-destinations, was taken into account not only their number, but also their status, and preservation as an integral object of tourist and excursion activity, proceeding from the coefficients proposed in formula 1 (Hyshchuk, 2016):

$$
\text { Снср }(\mathrm{s})=\sum \mathrm{k} \times \mathrm{x} 1+\mathrm{k} \times \mathrm{x} 2+\mathrm{k} \times \mathrm{x} 3+\mathrm{k} \times \mathrm{x} 4 \quad \text { “1” }
$$

CHCP (s) is the status capacity of HCS of different weights (values); $\mathrm{k}$ is the coefficient of the "status weight" of the HCS, where 1,2 are obtained by the significant sites of international (UNESCO heritage) values, 1.0 by the sites of national importance, 0.9 by the sites of state importance, 0.75 by the sites of local significance; and x1, x2, x3, x4 the number of HCSs, respectively, of international, national, state and local status (Hyshchuk, 2016).

The second factor component of the partial rating of the regional historical and cultural heritage in the study is a modified indicator (coefficient) of concentration of tourist destinations. It takes into account both the number of historical and cultural destinations, the total area on which they are located, and the tourists who visited them for a certain period of time, usually a year. The methodology of its calculation is presented in K. Polyvach using the formula (Polyvach, 2007):

$$
\mathrm{W}=\mathrm{V} / \sqrt{\mathrm{SP}} \ln \mathrm{B}
$$

$\mathrm{W}$ - modified index (coefficient) of concentration of tourist destinations;

$\mathrm{V}$ - absolute indicator of the number of objects of the historical and cultural heritage in the region;

$\mathrm{S}$ - area of the studied regions;

$\mathrm{P}-$ population of the region;

$\mathrm{B}-\sqrt{\mathrm{SP}}$.

The third factor component of the partial rating assessment of the regional historical and cultural heritage is the localization coefficient of the facilities. This factor takes into account the specific weight of the territory by the number of destinations and the specific weight of the territory by area. The order of its calculation is presented in the formula "3" (Polyvach, 2012).

$$
\text { Kloc }=\mathrm{Ch} / \mathrm{Cs}
$$$$
\text { "3" }
$$

$\mathrm{Ch}$ - specific weight of the region by the number of objects of historical and cultural heritage;

Cs - the region's share by area.

Consequently, the total rank value of all three factor components and their partial assessments of the region's historical and cultural heritage gives, as a result, an overall score in points (according to the rating) that a region has received. It is important that this evaluation has an inverse relationship (lower scores correspond to better and enhanced potentials). In other words, the authors have obtained a final picture of the aggregate of those 
territories that have a favorable concentration of historical and cultural tourist destinations, suitable for effective and perspective use in domestic and international tourism and excursion activities, as well as within the framework of associated EU membership and wider cross-border cooperation between Ukraine, Romania and other countries.

\section{RESEARCH RESULTS AND DISCUSSION}

Historical and cultural tourism resources are a set of territories, objects of material and spiritual culture created in the course of historical development and are objects of tourist interest. The category of historical and cultural resources (hereinafter referred to as "HCR") unites educative resources, event resources, ethnographic resources, and biographical and social resources (Beydyk, 2001). So the historical and cultural heritage is a collection of objects of cultural heritage taken over by mankind from previous generations. The object of historical and cultural heritage in tourist-excursion activities is the landmark, construction, complex, parts thereof, associated mobile objects, as well as territories or water objects, other natural, natural-anthropogenic or man-made objects, regardless of the state of preservation, which have survived and have value from an archaeological, aesthetic, ethnological, historical, architectural, artistic or scientific point of view and have retained their authenticity.

Estimation of the total number of HCSm in the Chernivtsi region showed that Kitsman, Khotyn, Zastavna districts and Chernivtsi city are the highest average of the indicators in the region (106). However, the total physical quantity of significant sites of a certain region can not act as a formative and predominant potential. Thus, according to the potential of significant sites in view of the status of their preservation value, it is necessary to "bring them down to a common denominator" and calculate the total rating potential of the Chernivtsi region, HCR, through the sum of the products of their quantity by the corresponding coefficients according to the formula " 1 ".

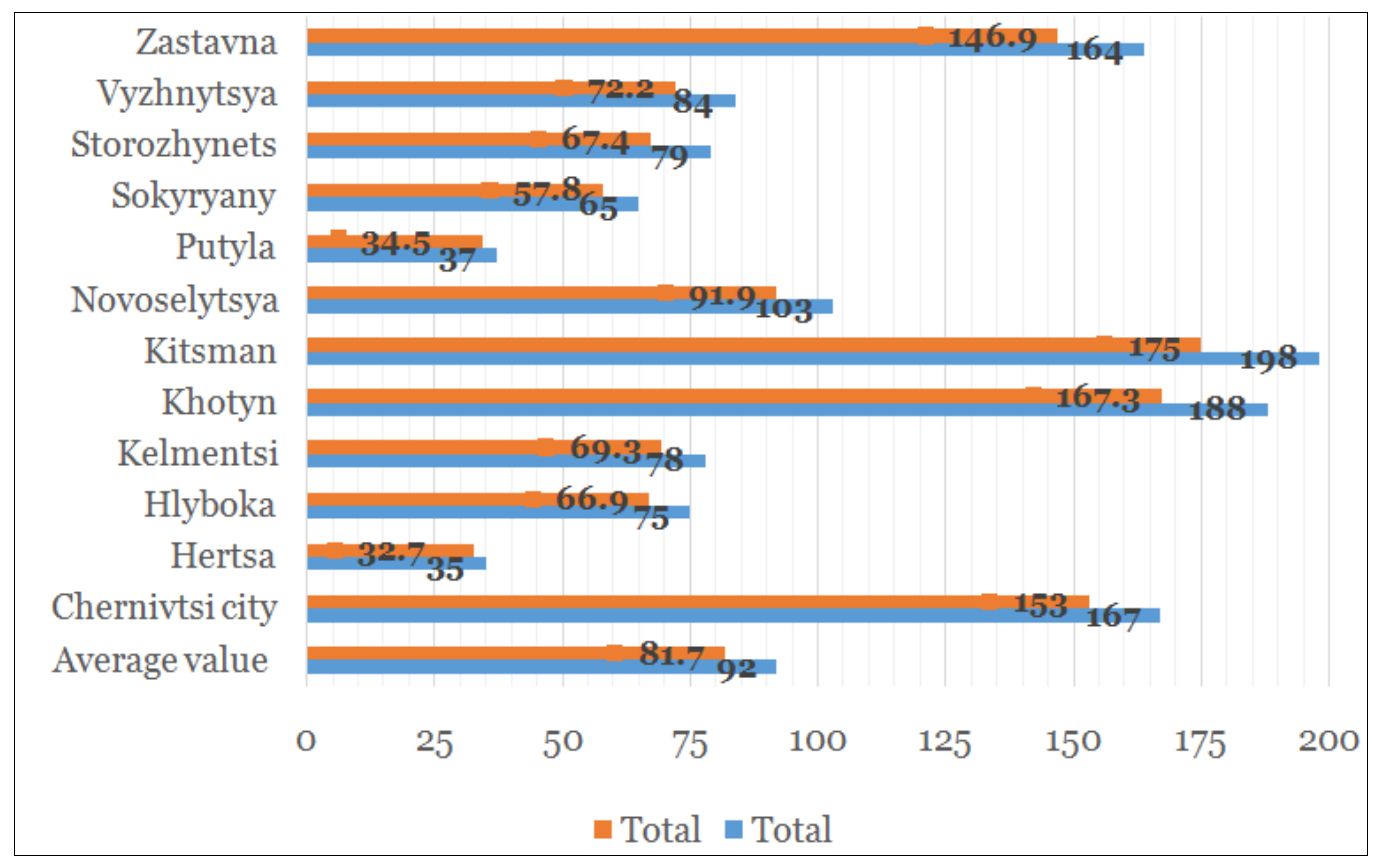

Figure 3. Number and rating assessment of historical and cultural heritage in the Chernivtsi region 
The average total rating of the potential of regional historical and cultural heritage, taking into account its preservation status coefficients, is currently 92 objects. Higher values of this value are concentrated in the Prut-Dniester region, including Chernivtsi city (153), Zastavna (146.9), Khotyn (167.3) and Kitsman (175). Novoselytsya also belongs to these areas, most of which are located in the valley of the river Prut. It is in this region of the Prut-Dniester Upland that, in our opinion, it is necessary to concentrate more attention in the formation of excursion tours that may be related to the resource use of the cultural heritage of the region (Figure 3).

For a more detailed analysis and correctness of the conclusions, it is expedient to determine not only the number of significant sites in these districts in general, but also the modified coefficients of concentration and localization of objects, given the areas they occupy and the population of the same areas. According to the total score of the archaeological heritage objects by the administrative units of the Chernivtsi region and the methodology for calculating the modified concentration indicators and the localization coefficient of tourist and excursion destinations, we calculated the total ratings of the administrative-territorial units for each of the three indicators (Table 1).

Table 1. The total rating evaluation of the potential of

archaeological heritage objects by the administrative units of the Chernivtsi region

\begin{tabular}{|c|c|c|c|c|c|c|c|}
\hline Districts & $\begin{array}{c}\text { State } \\
\text { archeological } \\
\text { heritage, points }\end{array}$ & تص & $\begin{array}{c}\text { Modified indicator } \\
\text { of the concentration } \\
\text { of objects }\end{array}$ & 赵 & $\begin{array}{c}\text { Object } \\
\text { localization } \\
\text { coefficient }\end{array}$ & : & 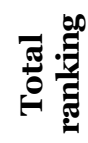 \\
\hline Chernivtsi city & $15 \cdot 3$ & 10 & 1.75 & 10 & 2.02 & 4 & 24 \\
\hline Hertsa & 9.9 & 11 & 1.23 & 11 & 0.63 & 8 & 30 \\
\hline Hlyboka & 32.4 & 5 & 3.66 & 5 & 0.98 & 6 & 16 \\
\hline Kelmentsi & 23.4 & 7 & 2.73 & 7 & 0.7 & 9 & 23 \\
\hline Khotyn & 70.2 & 2 & 7.96 & 2 & 1.98 & 2 & 6 \\
\hline Kitsman & 65.7 & 3 & 7.48 & 3 & 2.18 & 3 & 9 \\
\hline Novoselytsya & 42.3 & 4 & 4.73 & 4 & 1.16 & 5 & 13 \\
\hline Putyla & 0.0 & 12 & 0.00 & 12 & 0.0 & 12 & 36 \\
\hline Sokyryany & 24.3 & 6 & 2.83 & 6 & 0.74 & 7 & 19 \\
\hline Storozhynets & 18.0 & 8 & 1.94 & 8 & 0.31 & 11 & 27 \\
\hline Vyzhnytsya & 17.1 & 9 & 1.93 & 9 & 0.38 & 10 & 28 \\
\hline Zastavna & 82.8 & 1 & 9.59 & 1 & 2.7 & 1 & 3 \\
\hline Chernivtsi region & 401.4 & - & $35 \cdot 36$ & - & 1.0 & - & - \\
\hline Average value & 29.3 & - & $3 \cdot 36$ & - & 1.0 & - & 16 \\
\hline
\end{tabular}

Above average values of the modified indicator of the concentration of archaeological sites were formed in Zastavna district (9.59), Khotyn (7.96), Kitsman (7.48), Novoselytsya (4.73) and Hlyboka (3.66) districts. Below average, but close to them, were the second group of regions: Sokyryany and Kelmentsi, in which the indicated coefficient was respectively 2.83 and 2.73 . In the latter group, the territorial parts of the region are combined, where the integrated modified indicator took the least values. They include the areas of the Prut-Siret interfluve in the Carpathian region, as well as the city of Chernivtsi (1.75): Storozhynets (1.94), Vyzhnytsya (1.93) and Hertsa (1.23) districts.

There are no such monuments in Putyla district. For a more detailed explanation of the availability of archeological sites in the region, it is worthwhile analyzing the distribution of the localization coefficients for archaeological heritage sites. In this case, the optimal value should approach 1, since here the ratio of the shares of archaeological 
objects of the specific weight of the areas on which they are represented is taken into account. In general, a good concentration of such monuments is observed in Zastavna, Khotyn and Kitsman districts and in Chernivtsi, where they are concentrated twice as densely as in other regions. The second group of districts is formed by Novoselytsya (1.16) and Hlyboka (0.98) districts. The third group unites outsiders, which are located in the Carpathian Mountains, the mountainous part of the region and Northern Bessarabia. The localization coefficient in such areas is not enough, since it ranges from 0.31 (Storozhynets district) to 0.74 (Sokyryany).

Analysis of the value of the total potential of the administrative districts for archaeological sites showed the importance of Zastavna region, where this potential has achieved the best value, 3. Khotyn and Kitsman districts have quite powerful indicators, the ratings of which do not exceed 10 points. Taking into account the average value of the overall ratings for the region, which is 16, a group of districts is singled out, consisting of Novoselytsya and Hlyboka, whose indicators are close to that. Another group of districts (with the sum of the rating places which exceeded 16) were formed by Kelmentsi, Sokyryany, Vyzhnytsya, Storozhynets, Hertsa, Putyla and Chernivtsi city.

In the Chernivtsy region there are 113 sites of national importance, which are estimated at 113.2 points. Most sites of this status, taking into account the average value in the region of 7.6, are in the city of Chernivtsi (25.2), as well as in Kitsman (17), Khotyn (15), Hertsa (15), Putyla (12) and Zastavna (11) districts. So, half of the administrativeterritorial units have the average regional value. Good indices, although below average, are observed in Hlyboka district. Sokyryany and Storozhynets districts are characterized by the least values (2). In the Kelmentsy district, they are not registered at all (Table 2).

Table 2. The total rating evaluation of the potential of the objects

of the architecture of national significance by the administrative units of the Chernivtsi region

\begin{tabular}{|c|c|c|c|c|c|c|c|}
\hline Districts & $\begin{array}{c}\text { National } \\
\text { architectural } \\
\text { heritage, points }\end{array}$ & $\frac{20}{* 0}$ & $\begin{array}{c}\text { Modified indicator } \\
\text { of the concentration } \\
\text { of objects }\end{array}$ & 里 & $\begin{array}{c}\text { Object } \\
\text { localization } \\
\text { coefficient }\end{array}$ & ה & ชี \\
\hline Chernivtsi city & 25.2 & 1 & 2.88 & 1 & 11.71 & 1 & 3 \\
\hline Hertsa & 15 & 3 & 1.86 & 3 & 1.50 & 3 & 9 \\
\hline Hlyboka & 6 & 6 & 0.68 & 7 & 0.71 & 7 & 20 \\
\hline Kelmentsi & 0 & 10 & 0.00 & 12 & 0.00 & 12 & 34 \\
\hline Khotyn & 15 & 3 & 1.70 & 4 & 0.93 & 6 & 13 \\
\hline Kitsman & 17 & 2 & 1.94 & 2 & 1.81 & 2 & 6 \\
\hline Novoselytsya & 5 & 7 & 0.56 & 8 & 0.53 & 8 & 23 \\
\hline Putyla & 12 & 4 & 1.42 & 5 & 0.97 & 5 & 14 \\
\hline Sokyryany & 2 & 9 & 0.23 & 10 & 0.16 & 11 & 30 \\
\hline Storozhynets & 2 & 9 & 0.22 & 11 & 0.45 & 9 & 29 \\
\hline Vyzhnytsya & 3 & 8 & 0.34 & 9 & 0.35 & 10 & 27 \\
\hline Zastavna & 11 & 5 & 1.27 & 6 & 1.07 & 4 & 15 \\
\hline Chernivtsi region & 113.2 & - & 9.95 & - & 1.00 & - & - \\
\hline Average value & 7.6 & 8 & $\mathbf{0 . 8 7}$ & 5 & 0.89 & 5 & 15 \\
\hline
\end{tabular}

The average value of the modified indicator of the concentration of objects of national architecture heritage reached 0.87 . Proceeding from this, we note that half of administrative units exceed this value, namely Chernivtsi city (2.88), Kitsman (1.94), Hertsa (1.86), Khotyn (1.70), Putyla (1.42) and Zastavna (1.27) districts. Other areas are 
poorly provided with sites of national status, since their indicator is twice, or even more, inferior to the usual value: these are Vyzhnytsya (0.34), Sokyryany (0.23) and Storozhynets (0.22) districts. Exceptions to this list are Hlyboka (0.68) and Novoselytsya (0.56) districts. Evaluating the index of national heritage localization, taking into account its mean value, in region it reaches 0.89 and does not refer to sufficient quantities, since it is less than 1 . It should be noted that only 2 of 12 areas exceed the average value of objects' localization, Chernivtsi and Kitsman districts, and these are eleven higher than the optimal index. Putyla and Khotyn districts (0.97 and 0.93) are slightly inferior in the optimal index. Novoselytsya, Vyzhnytsya, Sokyryany and Storozhynets districts are distinctly different in this index, where it varies between 0.53 and 0.35. These areas, together with Kelmentsy, are least provided with architectural sites of national level, therefore they occupy the last places in the rating.

Note that for three indicators for objects of architecture of national significance, Chernivtsi clearly stands out as the absolute leader (the sum of the rating places has reached the minimum possible value, 3 ). Since the average total value of all ratings for the region is 15, this level does not exceed (according to the inversely proportional entity), except for the regional centre, also Kitsman, Hertsa, Khotyn, Putyla and Zastavna districts. Hlyboka, Novoselytsya, Vyzhnytsya, Storozhynets, Sokyryany and Kelmentsi districts scored higher values. For the first three the indicators can be considered more or less satisfactory, and for the last three the total score is defined as rather unsatisfactory (from 29 to 34). Throughout the Chernivtsi region there are 564 significant sites associated with important historical events in the life of the country and the region. Historical sites can be both architectural constructions, and places of military actions and grave sites of soldiers. Most of these attractions on state record are registered in Chernivtsi city, 125, which amounted to 92.7 points. Five regions have the higher average value (31.2) of indicators with scores in the range from 61.2 to 33.3. In general, the number of scores in regions with a value less than average is noticeable and ranges from 18.9 to 29.7. The exception is the Hertsa district, whose weight is at the lowest level (5.4) (Table 3).

Table 3. The total rating evaluation of the potential of historical

significant sites of state significance by the administrative units of the Chernivtsi region

\begin{tabular}{|c|c|c|c|c|c|c|c|}
\hline Districts & $\begin{array}{c}\text { State historical } \\
\text { heritage, points }\end{array}$ & 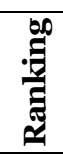 & $\begin{array}{c}\text { Modified indicator } \\
\text { of the concentration } \\
\text { of objects }\end{array}$ & : & $\begin{array}{c}\text { Object } \\
\text { localization } \\
\text { coefficient }\end{array}$ & : & 흉 \\
\hline Chernivtsi city & 92.7 & 1 & 10.61 & 1 & 10.76 & 1 & 3 \\
\hline Hertsa & 5.4 & 12 & 0.67 & 12 & 0.13 & 11 & 35 \\
\hline Hlyboka & 18.9 & 11 & 2.13 & 11 & 0.55 & 8 & 30 \\
\hline Kelmentsi & 37.8 & 5 & 4.41 & 5 & 1.02 & 4 & 14 \\
\hline Khotyn & 61.2 & 2 & 6.94 & 2 & 0.94 & 5 & 9 \\
\hline Kitsman & 60.3 & 3 & 6.87 & 3 & 1.59 & 2 & 8 \\
\hline Novoselytsya & 33.3 & 6 & 3.72 & 6 & 0.88 & 6 & 18 \\
\hline Putyla & 21.6 & 10 & 2.55 & 10 & 0.43 & 10 & 30 \\
\hline Sokyriany & 27.0 & 8 & 3.14 & 8 & 0.53 & 9 & 25 \\
\hline Storozhynets & 26.1 & 9 & 2.81 & 9 & 1.47 & 3 & 21 \\
\hline Vyzhnytsya & 29.7 & 7 & 3.35 & 7 & 0.85 & 7 & 21 \\
\hline Zastavna & 42.3 & 4 & 4.90 & 4 & 1.02 & 4 & 12 \\
\hline Chernivtsi region & 456.3 & - & 40.2 & - & 1.00 & - & - \\
\hline Average value & 31.2 & 5 & 3.58 & 5 & 0.91 & 5 & 16 \\
\hline
\end{tabular}


According to the modified indicator of the concentration of historical objects in the region, the absolute advantage of Chernivtsi (10.61) is again noted. The latter's value is three times more than the average and about twice as much as the second rated Khotyn district (6.94). Also, the average value (3.58) is lower than the Kitsman, Zastavna, Kelmentsi and Novoselytsya districts. Other areas do not reach the average. Moreover, the indicator of the last of them, Hertsa district, is 5 and 16 times less, respectively, than the average value and the leading city of Chernivtsi. Only 5 administrative-territorial units as for the localization of historical objects of national importance have indicators above the average: Chernivtsi city (10.76), Kitsman district (1.59), Storozhynets district (1.47), Zastavna and Kelmentsi districts (1.02). The minimum values are characteristic for a number of other areas, and Khotyn has a close to the average regional index (0.94). At the same time, the Hertsa district with the smallest localization parameter is four times lower (o.13) than the previous one in the coefficient rating of Putyla district (0.43).

The total rating evaluation of historical sites of state significance revealed the top three leaders in the Chernivtsi city, Kitsman and Khotyn districts. Incidentally, we note that the first of them holds the best position in all three indicators. The second group of territories of high values (from 12 to 16) is occupied by Zastavna and Kelmentsi districts. The third group is formed by regions with lower parameters: Novoselytsya, Storozhynets, Vyzhnytsya and Sokyryany districts, whose numerical expressions range from 17 to 25. The worst provided by historical sites are Hlyboka and Hertsa (Subcarpathians) and Putyla (Carpathians) districts. All sites of monumental art of national significance in the Chernivtsi region have a total value of 51.3 points, and their average value is 1.8 points. Their significant part is represented in Chernivtsi city, whose potential is estimated at 19.8 points. The mark of average value was reached also by Kitsman (7.2) and Novoselytsya (4.5) districts. Kelmentsi, Vyzhnytsya, Hlyboka and Khotyn districts have the same number of significant sites: 3.6. The smallest parametric indicators are fixed for Zastavna (1.8), Storozhynets (1.8), Hertsa (0.9) and Putyla (0.9) districts. There are no historical monuments in the Sokyryany district (Table 4).

According to the modified indicator of concentration of monumental art objects, Chernivtsi is far ahead of all other administrative-territorial entities. In particular, its coefficient is 6 times the average over the region. Closer, but larger than it, are Kitsman (o.82), Novoselytsya (0.503), Kelmentsi (0.42), Khotyn (0.408), Hlyboka (0.407) and Vyzhnytsya (0.406) districts. In the remaining areas, the value of the modified coefficients indicates a low concentration of the above-mentioned monuments, since the value of their parameters is less than the average for the region, o.36. The remaining areas do not exceed the average value. These are areas in which the modified coefficient is less than the average value of 0.36: Zastavna (0.208), Storozhynets (0.194), Putyla (o.106). In Sokyryany district, there are no sites of national importance.

The localization of objects of monumental art of state registration is excessive in Chernivtsi, as indicated by their coefficient, which acquired its highest value here and exceeded the nominally optimal figure by twenty times. Hlyboka (0.94) and Novoselytsya (1.06) can be categorized as regions with more or less optimal localization structure.

The rest of the districts are beyond the optimal regional structure of the objects of monumental art, but they can be reduced to at least two intervals: close to the optimal (more than 0.50) and very distant from it. The first include Vyzhnytsia, Storozhynets' and Kel'mentsi districts. The second interval is formed by Khotyn, Zastavna, Hertsa and Putyla districts. The Sokyryany district occupies a special place, since no objects of monumental art of state significance have been recorded on its territory. According to the total number of rating places for the objects of monumental art among administrative- 
territorial units, the top three are the city of Chernivtsi city (3 points) with Kitsman (6 points) and Novoselytsya (9 points) districts. Another group of regions centres around the usual total for the region, 15 points, namely Hlyboka, Kelmenetsi and Vyzhnytsya districts. This indicates their more or less sufficient supply of monuments of national importance. The second twenty areas where the total indicator is quite far from the ordinary value are rounded out by Khotyn (17 points) and Storozhynets (20 points). Others (Zastavna, Hertsa, Putyla and Sokyryany) are insignificant in terms of rating potential and it is difficult to count on them for tourist-excursion activities.

Table 4. Assessment of the potential of state record sites of monumental art by the administrative units of the Chernivtsi region

\begin{tabular}{|c|c|c|c|c|c|c|c|}
\hline Districts & $\begin{array}{c}\text { State art } \\
\text { monument } \\
\text { heritage, points }\end{array}$ & בี & $\begin{array}{c}\text { Modified indicator } \\
\text { of the concentration } \\
\text { of objects }\end{array}$ & 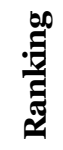 & $\begin{array}{c}\text { Object } \\
\text { localization } \\
\text { coefficient }\end{array}$ & 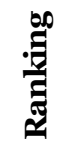 & 急 \\
\hline Chernivtsi city & 19.8 & 1 & 2.266 & 1 & 20.43 & 1 & 3 \\
\hline Hertsa & 0.9 & 6 & 0.111 & 10 & 0.2 & 10 & 26 \\
\hline Hlyboka & 3.6 & 4 & 0.407 & 6 & 0.94 & 4 & 14 \\
\hline Kelmentsi & 3.6 & 4 & 0.420 & 4 & 0.86 & 7 & 15 \\
\hline Khotyn & 3.6 & 4 & 0.408 & 5 & 0.49 & 8 & 17 \\
\hline Kitsman & 7.2 & 2 & 0.820 & 2 & 1.69 & 2 & 6 \\
\hline Novoselytsya & 4.5 & 3 & 0.503 & 3 & 1.06 & 3 & 9 \\
\hline Putyla & 0.9 & 6 & 0.106 & 11 & 0.16 & 11 & 28 \\
\hline Sokyryany & 0.0 & 7 & 0.000 & 12 & 0.00 & 12 & 31 \\
\hline Storozhynets & 1.8 & 5 & 0.194 & 9 & 0.90 & 6 & 20 \\
\hline Vyzhnytsya & 3.6 & 4 & 0.406 & 7 & 0.92 & 5 & 16 \\
\hline Zastavna & 1.8 & 5 & 0.208 & 8 & 0.39 & 9 & 22 \\
\hline Chernivtsi region & 51.3 & - & 4.52 & - & 1.00 & - & - \\
\hline Average value & 1.8 & 4 & 0.36 & 5 & 0.84 & 5 & 15 \\
\hline
\end{tabular}

The ordinary values of the total sum of places for four types of destinations (archaeological, architectural, historical, monumental objects) reached $23.6(\approx 24)$ position points, that is, the range of the average values for the region was within 21-27. So, the territories of Novoselytsya (21) and Hlyboka (26.5) have more or less satisfactory attractions. They can be considered as quite suitable for the development of tourist and excursion activities using all varieties of historical and cultural heritage and require priority investments in the development of infrastructure, its preservation, restoration and popularization in the domestic and international tourist markets. The high level of $\mathrm{HCPm}$ (20-15) is fixed in the north of the region in the Trans-Dniester section, therefore Zastavna (20) and Khotyn (16) districts can be combined into the North Trans-Dniester region with a significant HCP. Most of the historical and cultural attractions are concentrated in the west and in the centre of the Trans-Prut part of the Chernivtsi region, in the Kitsman area and in the city of Chernivtsi (interval $\leq 14$ ). In particular, within the first administrativeterritorial unit, the total amount of places in four historical and cultural destinations was 9 rating points, and in the other, 11. This territory will be designated as West-Prut region of notable development of historical and cultural attractions.

In general, the North Trans-Dniester and West Prut regions are geographically tangential, therefore they should be combined and designated as the North Bukovyna recreational supra-region with a significant concentration of HCPm. Low (28-33) and 
very low $(\geq 34)$ summary rating sites of the historical and cultural heritage components are concentrated in the Precarpathian region on the right side of the river Prut, the mountainous part of the region and the regions remote from Chernivtsi in the extreme eastern and southwestern regions: Kelmentsi (29 points), Vyzhnytsya (32.5), Storozhynets (34.5), Hertsa (36), Sokyryany (38) and Putyla (38.5) districts.

Within the framework of a certain administrative-territorial array, two areas of weak concentration of the HCPm are clearly distinguished: the East Bessarabian region (the Kelmentsi and Sokyryany districts) and the Precarpathian-Carpathian region (the Vyzhnytsya, Storozhynets and Putyla districts). A separate enclave is the Hertza district, in which, according to the results of similar prospective studies of the border territories of Moldova and Romania, it will be possible to develop recreational activities. Although the administrative-territorial allocations mentioned above have lower scoring indicators than usual, they can be identified as the areas of the second stage of long-term development of tourist and excursion activities for favourable investment management in the said territory (Figure 4).

So the most promising area for the organization of tourist and excursion activities using historical and cultural destinations is, in general, Upper-Dniester-Prut part of the Chernivtsi region, one third of which is concentrated around the city of Chernivtsi. It was this territory that first of all belonged to the old developed ethno-cultural territories in the Dniester valley, within which, in particular, there was the largest number of settlements of the Trypillia civilization. It also belonged to the Galicia-Volyn principality, the Shypyntsi land, the Moldavian principality and the Austro-Hungarian Empire as historical Bukovyna. All state-political entities left here a significant historical heritage of many cultures, ethnic groups and their traditions.

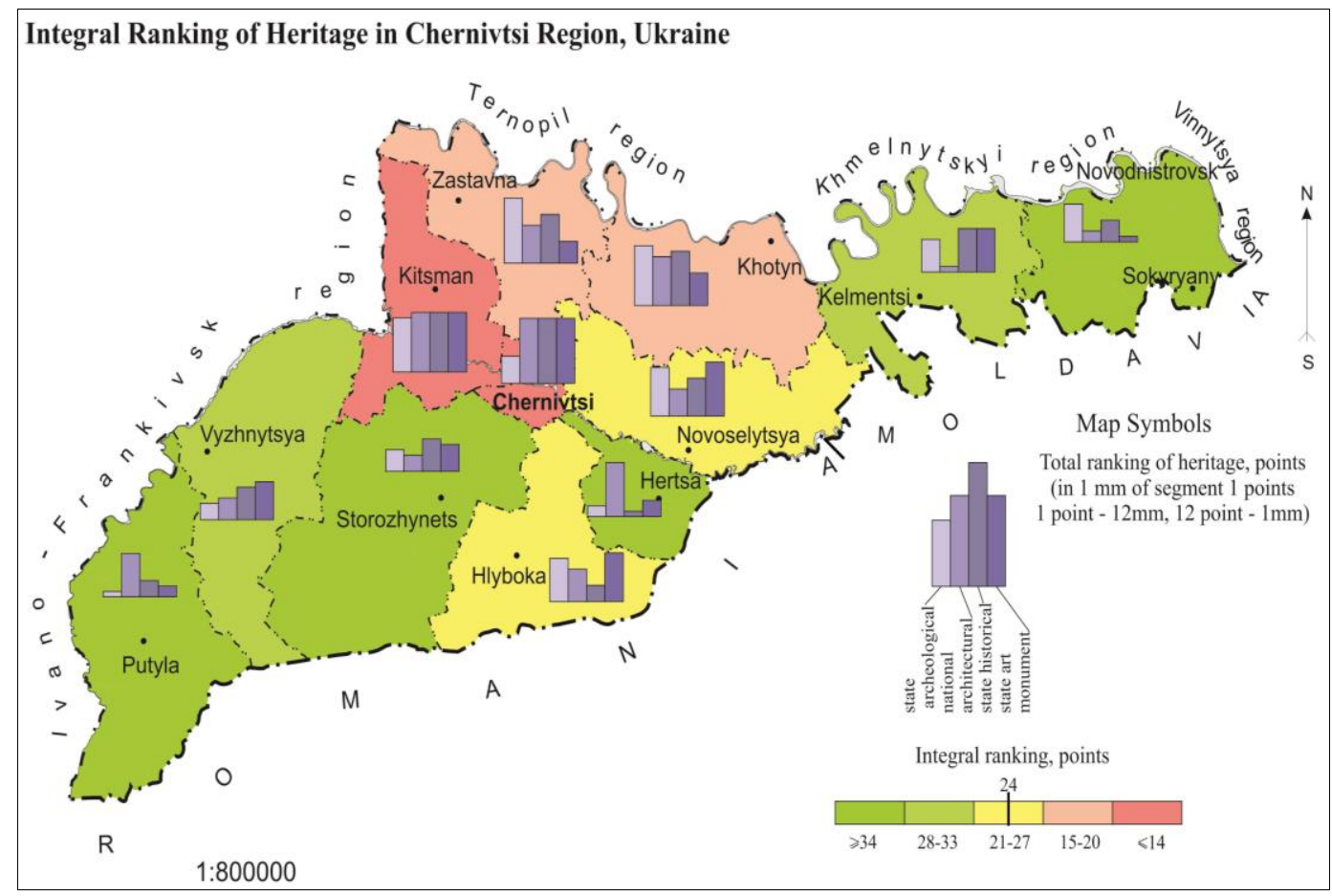

Figure 4. Integral ranking of heritage in Chernivtsi region, Ukraine 
Historical and Cultural Heritage of the Region and its Opportunities

in Tourism and Excursion Activities (Case of Chernivtsi Region, Ukraine)

\section{CONCLUSIONS}

For all rating positions, four types of destinations (archaeological, architectural, historical and objects of monumental art) are above average. The total summary rating values of the historical and cultural heritage of the Chernivtsi region are concentrated in the city of Chernivtsi and the administrative districts to the west and north. These lands are the most promising for the organization here of tourist and excursion activities using HCPm. Within their boundaries are the North Trans-Dniester and the West Prut regions, which are united in the North Bukovyna recreational supra-region. In general, throughout its historical development, this territory as historical Northern Bukovyna and Northern Bessarabia was a part of various civilizations and states. The most important among them were Trypillia and the Austro-Hungarian Empire, which left here a significant historical heritage of many cultures, ethnic groups and their traditions.

Taking into account the fact that Chernivtsi, despite the leadership in three positions (architectural, historical and monumental art objects), took second place in the research, we suggest that the city should be used more actively in new directions of tourist-excursion activity for its development, attractiveness and popularization. An additional argument for the full ability to use the historical and cultural heritage of the above-identified recreational areas in the tourist and recreational business is transport accessibility. Today there are important rail and road transport routes in this area, and the city of Chernivtsi is located $40 \mathrm{~km}$ from the state border with Romania. Chernivtsi has direct railway communication with the cities of Ivano-Frankivsk, Lviv, Kovel, Kiev, Odesa. From the end of 2015, between Chernivtsy and Lviv, there is a regional express of the Intercity + class (duration 3.5 hours), which passes through two important railway hubs of western Ukraine in Ivano-Frankivsk and Lviv.

This route allows tourists to make a transfer to high-speed trains "Intercity and Intercity $+"$ in Ivano-Frankivsk and to the most important tourist destinations in Ukraine, and in Lviv to Przemysl in Poland (travel time 1 hour 10 min.) and other Ukrainian tourist cities. According to another project, Chernivtsi is connected today by railway communication with Suceava and Bucharest in Romania with the change in Vadul-Siret. The international road transport corridor E-85 passes through the Chernivtsi region: Klaipeda (Lithuania) - Brest (Belarus) - Chernivtsi (Ukraine) - Siret (Romania). The main highways of national importance that pass through the PrutDnister Bukovyna and Bukovyna-Bessarabian Transprut recreational areas are: M-19 Domanovo (to Brest, Belarus) - Chernivtsi - customs crossing Mamalyga (to Chisinau, Moldova), M-20 Zhytomyr - Chernivtsi - customs transition Tereblechye (to Bucharest, Romania) and a number of regional and local roads.

In Chernivtsi there is an airport that serves only regular flights from Kiev and charter airlines during the summer vacation season for Ukrainian citizens. Now the nearest to the alternative routes mediated air communication with Chernivtsi city, constantly take regular and low-costers, for tourists there were Ivano-Frankivsk, Lviv, as well as Romanian Iasi, Bacau, Cluj-Napoca and the capital of Moldova Chisinau. The problems and prospects of direct passenger flights with Chernivtsi have been studied and discussed in the earlier publications (Hyshchuk \& Pylypets', 2016).

In 2017, 75 hotels and similar accommodation facilities operated in the Chernivtsi region (in the city of Chernivtsi 28 hotels), where 116,959 people were attended to. This is 9.7\% more than in the previous year, but only $5.8 \%$ of the settlers were citizens of 56 countries, but mostly from Romania, Belarus, Moldavia, Israel, Poland, Germany, Turkey and USA. It should be noted that a positive factor in this is that $68.0 \%$ in terms of the number of hotels and $81.3 \%$ of visitors account for the best recreational potential of the 
historical and cultural heritage determined. However, the extremely negative is the fact that foreigners and their minimum number of all the region's tourists lived mainly in hotels and similar accommodation facilities in Chernivtsi city. This once again points to the lack of comprehensive programs for the development and promotion of tourism and harmonious decentralization in the work of tourism and excursion specialists regarding the interest of foreigners in the historical and cultural heritage of peripheral but also interesting areas of the tourist destination. Another sign of such statistics is their underestimation of the potential and the lack of an actual innovative format and attraction of grant funds to the development of a tourist product for the Prut-Dniester Bukovyna and BukovynaBessarabian Transprut recreational areas. The most successful current format in this now can be considered quest-excursions. Their peculiarities are non-standard, where the guide is often absent, and the tourists themselves, using previously received information, embody its functions. In this case, the excursion route is formed so that at each point the excursionists, in addition to cognitive information about the object, receive various tasks, riddles, puzzles, etc., guessing which lead to the next destination.

According to the above considerations, a script for a developed quest "Austrian Chernivtsi in urban culture and architecture" has been already initiated for the "Tourist Bukovyna" Tourism Industry Association a script for a developed quest "Austrian Chernivtsi in urban culture and architecture", which currently successfully serves tourists and all comers through the streets of Chernivtsi. Another series of excursions for the same Association has been developed for areas with a rating above the average, which to as the "Civilizations of the ancient world of the Prut-Dniester", "Sacred objects and monasteries of the Transdniestrian Bukovyna" and "Roman civilizations of the Prut-Dniester Bukovyna". Another thematic excursion "Northern Bessarabia in the late Roman times" runs through the territory with lower rating points, but in the long term it provides for the popularization of archaeological tourism in scientific and personnel cooperation with the Department of the History of the Ancient World, Middle Ages and Museum Studies of Chernivtsi National University named after Yu. Fedkovych and the scientific department of the Chernivtsi Regional Museum of Local History and Ethnography, and the excursion "Historical and Cultural Heritage of the Romanian-speaking Bukovyna" will be in the part of the Precarpathian-Carpathian region, with the continuation of its routes to the neighbouring Suceava and Botosani districts of Romania.

All these tourist products are able to increase the competitiveness of the tourism industry using the regional historical and cultural heritage, to identify areas and specific places of investment and tourist attractions using their historical and cultural resources and to attract Ukrainian Bukovyna to a single region of transboundary cooperation of the Carpathian recreational zone in Ukraine and EU countries at the same time. The global prospect of our further scientific research may be the identification, in accordance with the methodology proposed above, and a detailed analysis of those potential territories of the Ukrainian Carpathians in other areas (Lviv, Ivano-Frankivsk, Transcarpathia) that have highly preserved historical and cultural heritage destinations for the development and continuation of relevant thematic tours involving countries on adjacent border areas - not only Romania but also Poland and Slovakia.

\section{REFERENCES}

Adejuvvon, F., (1985). Cultural heritage as tourism product. The Tourist Review, Vol. 40, pp.19-21.

Bayteriakov, A., (1996). Geographical aspects of formation and development mountain tourism and recreation systems (case of Crimea). Odesa, $17 \mathrm{p}$. 
Beydyk, O. (2001). Recreational and tourist resources of Ukraine: methodology and methods of analysis, terminology, zoning. Kyiv, $395 \mathrm{p}$.

Boissevain, J. (1977). Tourism and Development in Malta. Development and Change, pp. 523-538.

Chiabai, A., Platt, S., \& Strielkowski, W., (2014), Eliciting Users' Preferences for Cultural Heritage and TourismRelated E-Services: A Tale of Three European Cities. Tourism Economics, Vol. 20, pp. 263-277.

Coccossis, H., (2009). Sustainable Development and Tourism: Opportunities and Threats to Cultural Heritage from Tourism, Cultural Tourism and Sustainable Local Development. Part I, Chapter 4, London, pp. 47-57.

Cuccia, T., \& Cellini, R., (2007). Is cultural heritage really important for tourists? A contingent rating study. Journal Applied Economics, Vol. 39, pp. 261-271.

Evdokymenko, V., (1996). Regional policy of tourism development: Methodology of formation, mechanism of realization. Chernivtsi, $287 \mathrm{p}$.

Filonenko, I., (2005). Territorial recreational complex of Chernihiv region. Kyiv, 23 p.

Hyshchuk, R., (2016). Potential of historical and cultural monuments of Chernivtsi region in the context of development of tourist-excursion activities, From geography to geographic Ukrainian studies: the evolution of educational and scientific ideas and searches. Chernivtsi, pp. 125-127.

Hyshchuk, R., \& Pylypets', O., (2016). Transport Accessibility as Factor of Excursion Tourism Development (Case of Chernivtsi, Ukraine). The Journal of Social and Economic Geography, Kharkiv, Vol. 20 (1), pp. 91-96.

Kartashevska, I., (1995). Geographical Aspects of Using the Excursion Potential of Crimea in the Conditions of Market Relations. Kyiv, 22 p.

Kuznetsov, M., (1995). Complex zoning of resources for the development of tourist and excursion activities in the Crimea, Development of tourism in Ukraine, Problems and prospects. Kyiv, pp. 84-94.

Kuzyk, S., \& Kasianchuk, Z., (1993). Estimation of tourist suitability of the territory of the Carpathians. Ukrainian Bridge to Europe: Problems and Prospects, Lviv, 1993, p. 111.

Litovka, L., (1990). Development and territorial organization cognitive tourism in the recreational system of the Leningrad region. Leningrad, $20 \mathrm{p}$.

Matsola, V., (1997). Recreational and tourist complex of Ukraine. Lviv, $259 \mathrm{p.}$

Panchenko, T., (1998). Scientific and methodological aspects of the organization regional tourism systems of historical and urban development heritage. History of Tourism in Ukraine, pp.45-55.

Pavlov, V., \& Cherchyk, L., (1998). Recreation Complex of Volyn: Theory, Practice. Perspectives, Lutsk, 122 p.

Pirozhnik, I., (1985). The fundamentals of the geography of tourism and excursion activities. Minsk, 253 p.

Pokolodna, M., (2003). Recreational resources of Kharkiv region, geographical characteristics and rational using. Simpheropol, 20 p.

Polyvach, K., (2007). Cultural heritage and its influence on the development of regions of Ukraine (sociogeographical research). Kyiv, 24 p.

Polyvach, K., (2012). Cultural Heritage and its Influence on Development of Regions of Ukraine. Kyiv, 208 p.

Yakovenko, I., (2004). Theoretical and methodological foundations of recreational nature using (sociogeographical research). Simpheropol, $32 \mathrm{p}$.

Zavada, V., (1998). Architectural heritage of Ukraine as an object tourism. Regional aspect, Tourism in Ukraine: economy and culture, pp. 23-28.

*** List of monuments and objects of cultural heritage of Chernivtsi city. Retrieved from: chernivtsy.eu/portal/f/files/list_kult_heritage.doc

*** The register of monuments in Chernivtsi region. Retrieved from: http://web.archive.org/web/ 20081231045810/http://www.heritage.com.ua/reestry/index.php?id=75;

*** The register of heritage of national value. Retrieved from: http://mincult.kmu.gov.ua/control/ uk/publish/article?art_id=245365203\&cat_id=244910406

*** The register of heritage of local value. Retrieved from: http://mincult.kmu.gov.ua/control/ uk/publish/article?art_id=245323810\&cat_id=244910406

*** Tourism and Rest in Chernivtsi Region. Statistical collection, 2017, Chernivtsi, 90 p.

Submitted:

14.07.2018
Revised:

19.11.2018
Accepted and published online 22.11.2018 